Quebec Cooperative Study

on Friedreich's Ataxia

\title{
Effect of Asparagine, Glutamine and Insulin on Cerebral Amino Acid Neurotransmitters
}

\author{
ROGER F. BUTTERWORTH, FRANCE LANDREVILLE, EDITH HAMEL, ANDREA MERKEL, \\ FRANÇOIS GIGUERE, ANDRÉ BARBEAU
}

SUMMARY: Treatment of rats with asparagine or glutamine caused substantial increases in glutamine concentrations in cerebellum and medulla oblongata. Insulin treatment caused a diminution of glutamate and GABA in these regions of brain. Since it is now well-established that glutamine is a very efficient precursor of the neurotransmitter pool of glutamate in mammalian brain, treatment with asparagine or glutamine could be of therapeutic (replacement) value in the treatment of neurological disorders such as Friedreich's ataxia, in which cerebral glutamate concentrations have been found to be diminished.

RESUME: L'injection d'asparagine ou de glutamine, chez le rat, cause une augmentation substantielle de la concentration de la glutamine au niveau du cervelet et de la medulla oblongata. Une injection d'insuline cause une diminution du glutamate et du GABA dans ces mêmes régions $d u$ cerveau. Étant donné qu'il est maintenant bien établi que la glutamine est un précurseur très efficace du pool neurotransmetteur de glutamate, dans le cerveau des mammifères, le traitement à l'asparagine ou la glutamine pourrait être une approche thérapeutique (remplacement) pour le traitement de désordres neurologiques comme l'Ataxie de Friedreich, dans laquelle, les concentrations de glutamate cérébral sont diminuées.

From the Clinical Research Institute of Montreal.

Reprint requests for the complete supplement on Friedreich's Alaxia (phase three) to: Dr. André Barbeau, Clinical Research Institute of Montreal, 110 Pine Avenue West, Montreal, Quebec, Canada, H2W IR7.

\section{INTRODUCTION}

There is increasing evidence that the dicarboxylic amino acids glutamate and aspartate may function as excitatory neurotransmitters in the mammalian central nervous system. One region of brain in which there is convincing evidence for a neurotransmitter role for these amino acids is cerebellum where, using biochemical and electrophysiological indices, the presence of glutamatergic and aspartagergic neurons has been postulated in the parallel fibers originating from the granule cells (Roffler-Tarlow and Sidman, 1978) and in climbing fibers originating from the inferior olive (Guidotti et al., 1975; Butterworth et al., 1978).

Recent studies by the Quebec Cooperative Study of Friedreich's Ataxia have shown (Huxtable et al., 1979) that glutamate, aspartate and the metabolically related inhibitory amino acid GABA are present in diminished concentrations in cerebellar hemispheres and vermis of patients dying with Friedreich's ataxia. Diminished aspartate concentration had previously been reported in the cerebella of patients diagnosed as having a dominantly inherited cerebellar ataxia (Perry et al., 1977). Furthermore, cerebellar glutamate concentrations were reportedly reduced in genetically ataxic mice (WeaverStaggerer) (Roffler-Tarlov and Sidman, 1978; McBride et al., 1976) and in experimental ataxia produced by 3acetyl pyridine-induced degeneration of cerebellar climbing fibers in the rat (Guidotti et al., 1975).

The amino acids glutamate and aspartate are synthesized in nerve terminals from glucose (Shank and Aprison, 1979) so that genetically inherited disorders in which these amino acids are found to be selectively modified might be expected to show associated abnormalities of glucose metabolism. This appears to be the case; it is now well established that abnormalities of glucose metabolism are frequently present in inherited ataxia (Shapcott et al., 1976; Thoren, 1962; Barbeau et al., 1976). There are reports (Blass et al., 1970; Lonsdale et al., 1969; Wick et al., 1977) in which hereditary ataxia was found to be associated with an inherited defect of pyruvate decarboxylase, the first enzyme of the pyruvate dehydrogenase complex. Another report suggested (Rodriguez-Budelli and Kark, 1978) that Friedreich's ataxia may be the result of an inherited defect of lipoamide dehydrogenase, the third enzyme present in both the pyruvate and $\alpha$-ketoglutarate dehydrogenase complexes. This finding, however, was not confirmed by others (Filla et al., 1978; Melançon et al., 1978; Stumpf et al., 1979).

The search continues for the primary defect in most of the inherited ataxias. Meanwhile, there is a considerable body of evidence, both of a direct and indirect nature, to suggest that the problems of coordination of movement (ataxia) may be related to the changes in concentration of the amino acid neurotransmitters glutamate and aspartate found in this class of degenerative diseases of the central nervous system.

Surprisingly little work has been done to attempt to modify the concentration of these amino acids in specific regions of the brain. The present study was undertaken to investigate the possibility that the precursor amino acids glutamine and asparagine, both known to cross the blood-brain barrier by the neutral amino acid carrier system (Oldendorf and Szabo, 1976) may cause increases in glutamate and aspartate respec- 


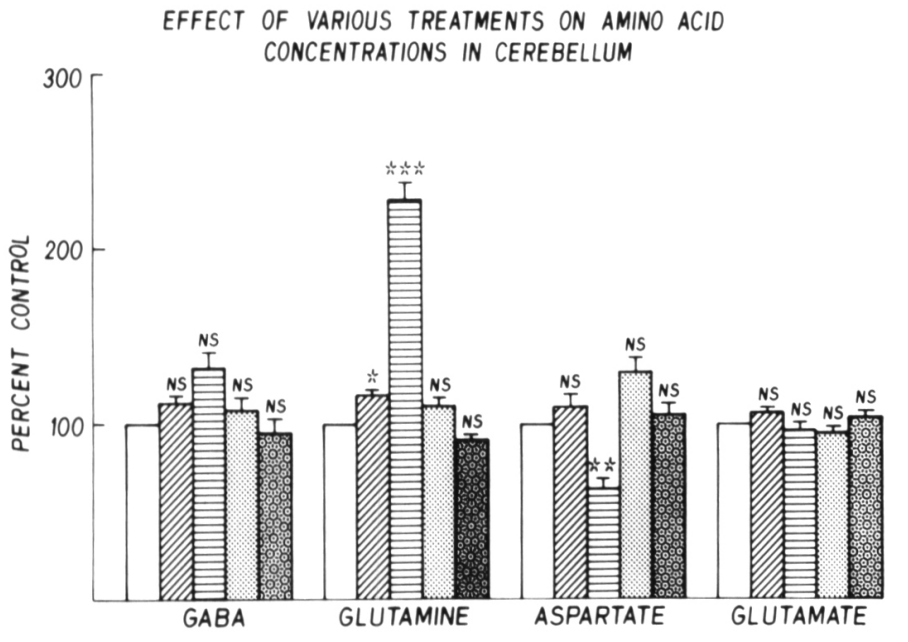

Figure 1

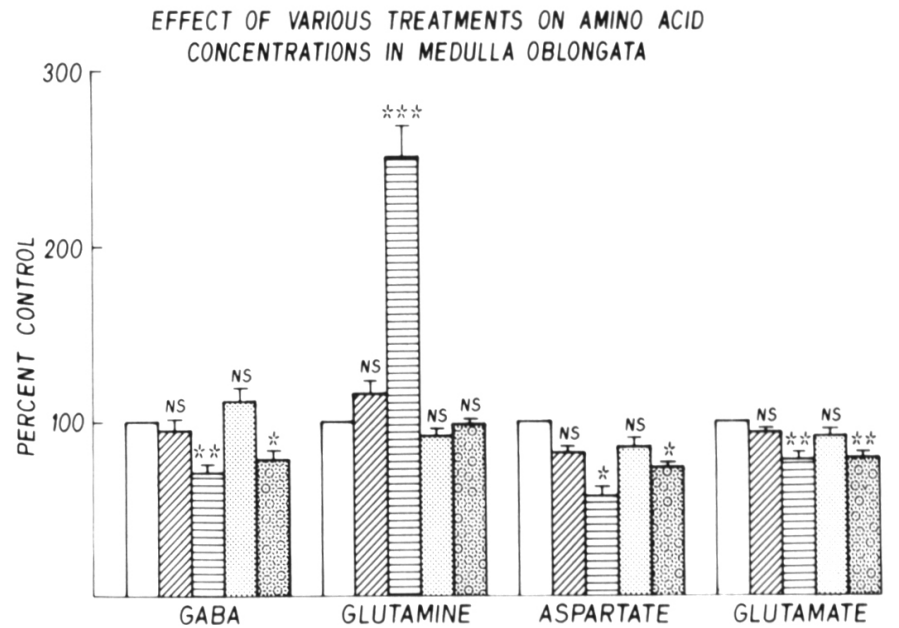

Figure 2

Legend for Figures $1 \& 2$

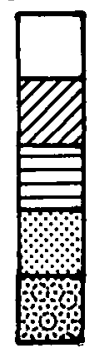

Appropriate vehicle-treated control group (see text for details).

Treatment with asparagine ( 1 g. per kg., per o.s.) 2 h. prior to sacrifice.

Treatment with glutamine $(2$ g. per kg., i.p.) 1 h. prior to sacrifice.

Treatment with insulin ( 2 i.u. per kg., i.p.) 2 h. prior to sacrifice ( 24 h. fasted rats).

Treatment with insulin ( 5 i.u. per kg., i.p.) 2 h. prior to sacrifice ( 24 h. fasted rats).

${ }^{* *} \mathrm{p}<0.01,{ }^{*} \mathrm{p}<0.05$, N.S. no significantly different from control group.

tively. In addition, the effect of insulin on cerebral amino acid distribution was included as it had previously been reported that treatment with the hormone led to increases in aspartate in brain (Tews et al., 1965). Cerebellum and medulla oblongata were the regions of brain chosen for study since it is these regions that are most frequently implicated in the inherited ataxias.

\section{MATERIALS AND METHODS}

Adult male Sprague-Dawley rats weighing $200-250 \mathrm{~g}$. were injected with the solutions of amino acid or insulin in the doses and via the route shown below:

Groups of 8 rats were used throughout. Control animals for each treatment received equivalent volumes of the appropriate vehicle. Rats were sacrificed $1 \mathrm{~h}$. after administration of glutamine and $2 \mathrm{~h}$. after asparagine or insulin; brains were rapidly removed and, within $30 \mathrm{sec}$. cerebellum and medulla oblongata dissected on ice.

*Amino acids refered to in this study are L-isomers in all cases.
Tissues were stored in liquid nitrogen until the time of assay. Regions were separately homogenised in $10 \mathrm{vol}$. $\mathrm{HClO}_{4}(0.48 \mathrm{M})$ and the amino acids GABA, glutamate, aspartate and glutamine assayed by the dansyl microtechnique previously described (Butterworth et al., 1978). Radiolabeled ${ }^{14} \mathrm{C}$-glutamate, aspartate and glutamine, as well as ${ }^{3} \mathrm{H}$-dansyl chloride were purchased from New England Nuclear, ${ }^{14} \mathrm{C}-\mathrm{GABA}$ from Amersham Searle, insulin (NPH) from Connaught Labs, and L-asparagine and L-glutamine from Sigma. Micropolyamide tlc plates were purchased from Schleicher and Schuell. All solvents were reagent grade and double-distilled deionised water was used throughout.

\section{RESULTS}

L-aspargine in a dose of $1 \mathrm{~g}$. per $\mathrm{kg}$. had no effect on glutamate, aspartate or GABA concentrations in either cerebellum or medulla oblongata (Figures 1 and 2) in rats sacrificed $2 \mathrm{~h}$. following administration.

There was, however, a small but significant increase in the concentration of glutamine in cerebellum following administration of asparagine. No changes were found in glutamine in medulla oblongata.

L-Glutamine in a dose of $2 \mathrm{~g}$. per $\mathrm{kg}$. produced the changes in amino acids shown in Figures 1 and 2. As can clearly be seen, $1 \mathrm{~h}$. following administration of glutamine, the most significant effect $(p<0.001)$ was a $2-3$ fold increase in glutamine in both cerebel-

\begin{tabular}{|l|c|c|c|l|}
\hline \multicolumn{1}{|c|}{ TREATMENT } & $\begin{array}{c}\text { NUTRITIONAL } \\
\text { STATE }\end{array}$ & DOSE & ROUTE & VEHICLE \\
\hline Asparagine* & Fed & 1 g. per kg. & p.o. & $\begin{array}{l}\text { 0.4\% methyl } \\
\text { cellulose in } \\
\text { saline } \\
\text { saline }\end{array}$ \\
Glutamine & Fed & 2 g. per kg. & i.p. & saline \\
Insulin & Fasted & 2 i.u. per kg. & i.p. & saline \\
Insulin & Fasted & 5 i.u. per kg. & i.p. & \\
\hline
\end{tabular}


lum and medulla oblongata. At first sight it might be argued that the increase in cerebral glutamine may be caused by contamination with blood glutamine in the brain. Wurtman and co-workers (Liebschutz et al., 1977) recently showed that blood glutamine was $2.2 \mu$ moles $/ \mathrm{ml} \mathrm{l} \mathrm{h}$. following administration of glutamine $2 \mathrm{~g}$. per kg. i.p.; i.e.: conditions identical to those used in the present experiment. Assuming that each gram of rat brain contains $20 \mu \mathrm{l}$ of blood (Liebschutz et al., 1977), one can calculate that 0.05 $\mu$ moles per $\mathrm{g}$. of brain glutamate is due to blood contamination. This represents less than $1 \%$ so that the changes shown in Figures 1 and 2 are clearly not due to blood glutamine. In addition to the changes in cerebral glutamine following administration of the amino acid there were substantial decreases in the other amino acids in brain: glutamate and GABA levels were significantly decreased $(p>0.01)$ in medulla oblongata and aspartate was significantly decreased in both brain regions.

Insulin administered to $24 \mathrm{~h}$. fasted rats in doses of 2 or 5 i.u. per kg., i.p. produced changes in cerebral amino acids in medulla oblongata only. The changes (decreased glutamate, aspartate and GABA) were apparent only following the highest dose of insulin.
The most significant change $(\mathrm{p}<0.01)$ was a diminished glutamate.

\section{DISCUSSION}

The fact that none of the treatments investigated caused significant increases in the concentrations of the dicarboxylic amino acids glutamate and aspartate supports the notion that these substances, known to possess neurotoxic properties, are effectively prevented from excessive accumulation in brain either by a) active transport out of brain or b) conversion into (and perhaps storage as) glutamine and $\mathrm{N}$-acetyl aspartate.

Figure 2 shows that insulin causes significant decreases in the amino acids glutamate and GABA, confirming previous reports (Tews et al., 1965). Increased aspartate reported with convulsive doses of insulin was not apparent at the dose used in this study. It has been suggested that glutamate may be consumed as an alternative (endogenous) energy source in insulin hypoglycemia.

Asparagine had no effect on aspartate concentrations in either of the two regions of brain. The only effect of asparagine administration was a significant increase in cerebellar glutamine. There are two possible mechanisms to explain this finding: firstly asparagine could be taken up by brain, trans-

\section{METABOLIC RELATIONSHIPS BETWEEN GLUCOSE AND AMINO ACID NEUROTRANSMITTERS IN BRAIN}

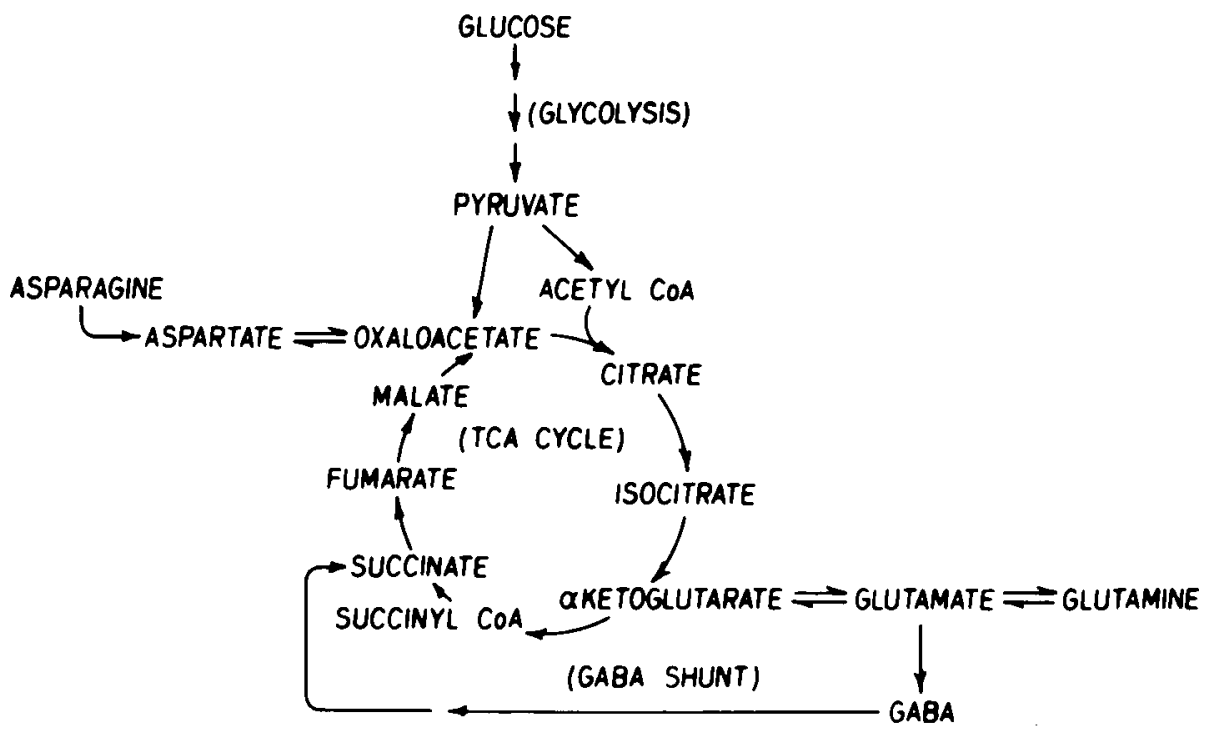




\section{REFERENCES}

BARBEAU, A., BUTTERWORTH, R.F., NGO, T., BRETON, G., MELANÇON, S., SHAPCOTT, D., GEOFFROY, G. and LEMIEUX, B. (1976). Pyruvate metabolism in Friedreich's ataxia. Can. J. Neurol. Sci., 3, 379-388.

BLASS, J.P., AVIGAN, J. and UHLENDORF, B.W. (1970). A defect in pyruvate decarboxylase in a child with an intermittent movement disorder. J. Clin. Invest., 49, 423-432.

BUTTERWORTH, R.F., HAMEL, E., LANDREVILLE, F. and BARBEAU, A. (1978). Cerebellar ataxia produced by 3-acetyl pyridine in rat. Can. J. Neurol. Sci., 5, 131-133.

FILLA, A., BUTTER WORTH, R.F., GEOFFROY, G., LEMIEUX, B. and BARBEAU, A. (1978). Serum and platelet lipoamide dehydrogenase in Friedreich's ataxia. Can. J. Neurol. Sci., 5, 111-114.

GUIDOTTI, A., BIGGIO, G. and COSTA, E. (1975). 3-acetyl pyridine: a tool to inhibit the tremor and the increase of cGMP content in cerebellar cortex elicited by harmaline. Brain Res., 96, 201-205.

HAMBERGER, A.C, CHIANG, G.H., NYLEN, E.S., SCHEFF, S.W. and COTMAN, C.W. (1979). Glutamate as a CNS transmitter. 1. Evaluation of glucose and glutamine as precursors for the synthesis of preferentially released glutamate. Brain Res., 168, 513-530.

HAWKINS, R.A. and BIEBUYCK (1979). Ketone bodies are selectively used by individual brain regions. Science, 205, 325327.

HUXTABLE, R., AZARI, J., REISINE, T., JOHNSON, P., YAMAMURA, H. and BARBEAU, A. (1979). Regional distribution of amino acids in Friedreich's ataxia brains. Can. J. Neurol. Sci., 6, 255-258.
LIEBSCHUTZ, J., AIROLDI, L., BROWNSTEIN, M.J., CHINN, N.G. and WURTMAN, R.J. (1977). Regional distribution of endogenous and parenteral glutamate, aspartate and glutamine in rat brain. Biochem. Pharmacol., 26, 443-446.

LONSDALE, D., FAULKNER, W.R., PRICE, J.W. and SMEBY, R.R. (1969). Intermittent cerebellar ataxia associated with hyperpyruvic acidemia, hyperalaninemia and hyperalanimuria. Pediatr., 43, 1025-1034.

McBRIDE, W.J. APRISON, M.H. and KUSANO, K. (1976). Contents of several amino acids in the cerebellum, brain stem and cerebrum of the 'staggerer', 'weaver' and 'nervous' neurologically mutant mice. J. Neurochem., 26, 867-870.

MELANÇON, S.B., POTIER, M., DALLAIRE, L., FONTAINE, G., GRENIER, B., LEMIEUX, B., GEOFFROY, G. and BARBEAU, A. (1978). Lipoamide dehydrogenase in Friedreich's ataxia Fibroblasts. Can. J. Neurol. Sci., 5, 115-118.

OLDENDORF, W.H. and SZABO, J. (1976). Amino acid assignment to one of three blood-brain barrier amino acid carriers. Am. J. Physiol., 230, 94-98.

PERRY, T.L., CURRIER, R.D., HANSEN, S. and MacLEAN, J. (1977). Aspartate-taurine imbalance in dominantly inherited olivoponto-cerebellar atrophy. Neurology, 27, 257261.

RODRIGUEZ-BUDELLI, $M$. and KARK, R.A.P. (1978). Kinetic evidence for a structural abnormality of lipoamide dehydrogenase in two patients with Friedreich's ataxia. Neurology, 28, 1283-1286.

ROFFLER-TARLOV, S. and SIDMAN, R.L. (1978). Concentrations of glutamic acid in cerebellar cortex and deep nuclei of normal mice and weaver, staggerer and nervous mutants. Brain Res., 142, 269-283.

SCHWERIN, P., BESSMAN, S.P. and WAELSCH, H. (1950). The uptake of glutamic acid and glutamine by brain and other tissues of the rat and mouse. J. Biol. Chem., 184, 37-44.

SHANK, R.P. and APRISON, M.H. (1979). Biochemical aspects of the neurotransmitter function of glutamate in "glutamic Acid: Advances in biochemistry and physiology", Ed. L.J. Filer Jr., S. Garattini, M.R. Kare, W.A. Reynolds and R.J. Wurtman. p. 139. Raven Press.

SHAPCOTT, D., MELANCON, S., BUTTERWORTH, R.F., KHOURY, K., COLLU, R., BRETON, G., GEOFFROY, G., LEMIEUX, B. and BARBEAU, A. (1976). Glucose and insulin metabolism in Friedreich's ataxia. Can. J. Neurol. Sci,, 3, 361364.

STUMPF, D.A. and PARKS, J.K. (1979). Friedreich's ataxia II. Normal kinetics of lipoamide dehydrogenase. Neurol., 29, 820 826.

TEWS, J.K., CARTER, S.H. and STONE, W.E. (1965). Chemical changes in the brain during insulin hypoglycaemia and recovery. J. Neurochem., 12, 679-693.

THOREN, C. (1962). Diabetes Mellitus in Friedreich's Ataxia. Acta. Paediat., 5I, suppl. 135, 239-247.

WICK, H., SCHWEIZER, K, and BAUMGARTNER, R. (1977). Thiamine dependency in a patient with congenital lacticacidaemia due to pyruvate dehydrogenase deficiency. Agents and actions, 7, 405-410. 